\title{
Clear Cell Renal Cell Carcinoma with Intratumoral Granulomatous Reaction: A Case Report and Review of the Literature
}

\author{
Hayeon Kim · Jong Wook Kim ${ }^{1}$ \\ Aeree Kim · Hyeyoon Chang \\ Departments of Pathology and ${ }^{1}$ Urology, \\ Korea University Guro Hospital, Seoul, Korea \\ Received: July 4, 2016 \\ Revised: August 26, 2016 \\ Accepted: September 7, 2016

\section{Corresponding Author} \\ Hyeyoon Chang, MD \\ Department of Pathology, Korea University Guro \\ Hospital, 148 Gurodong-ro, Guro-gu, Seoul 08308 \\ Korea \\ Tel: +82-2-2626-1470 \\ Fax: +82-2-2626-1481 \\ E-mail: breakfree83@hanmail.net
}

Granulomatous reaction associated with clear cell renal cell carcinoma (CCRCC) is a rare finding, and only a few cases have been described in the literature. It is postulated to occur due to cancer-related antigenic factors such as cancer cells themselves or soluble tumor antigens shed into the blood. Herein, we describe a case of a 56-year-old male patient diagnosed with CCRCC with intratumoral granulomatous inflammation.

Key Words: Carcinoma, renal cell; Granulomatous reaction; Kidney neoplasms
Granulomatous inflammation is a distinctive pattern of chronic inflammation composed of activated macrophages and $\mathrm{T}$ lymphocytes. ${ }^{1}$ Central necrosis is often accompanied. Granulomatous reaction occurs in various noninfectious or infectious conditions. Leading causes of granulomatous inflammation include systemic sarcoidosis and tuberculosis.

Granulomatous reaction in tumor stroma is an uncommon phenomenon but well defined in several tumors. ${ }^{2}$ Granulomatous reaction associated with tumor in patients without sarcoidosis or infection have been designated as tumor-related sarcoidlike reaction (SLR). ${ }^{3}$ Tumor-related SLR has been found in association with various malignant lesions including the breast, lung, and kidney cancers and hematologic malignancy such as Hodgkin's and non-Hodgkin's lymphomas. ${ }^{2,4-6}$ We present a unique case of a clear cell renal cell carcinoma (CCRCC) associated with extensive tumor-related SLR and a brief review of the literature.

\section{CASE REPORT}

A 56-year-old male with a history of deep vein thrombosis located in left common iliac vein and hypertension underwent thromboembolectomy in July 2015. Contrast-enhanced computed tomography (CT) scan revealed a renal cyst with internal enhancing structure in the upper pole of the right kidney, which measured $1.6 \mathrm{~cm}$. On follow-up CT scan after 6 months, the largest diameter of the renal cyst increased to $5.6 \mathrm{~cm}$. He complained of no specific symptom. Renal function test and urinalysis were unremarkable. The patient went through a partial nephrectomy on January 2016. He had an uneventful periand postoperative course. On a thorough clinical workup, he had no history, signs and clinical findings suggestive of sarcoidosis or tuberculosis.

Gross examination revealed a $5.3 \mathrm{~cm} \times 4.0 \mathrm{~cm} \times 2.8 \mathrm{~cm}$-sized well-encapsulated cortical cyst. The cystic space was mainly filled with old blood but also displayed a tan-colored solid mass measuring $2.2 \mathrm{~cm} \times 1.4 \mathrm{~cm} \times 1 \mathrm{~cm}$ (Fig. 1). The renal capsule was grossly intact.

Histopathologic examination revealed a CCRCC of Fuhrman nuclear grade 2, without sarcomatoid differentiation. The tumor contained areas of hemorrhage and coagulative necrosis. The tumor was well-delineated from surrounding normal renal parenchyma. There was no discrete fibrous capsule around the tumor. Multiple non-necrotizing granulomas of various sizes with 


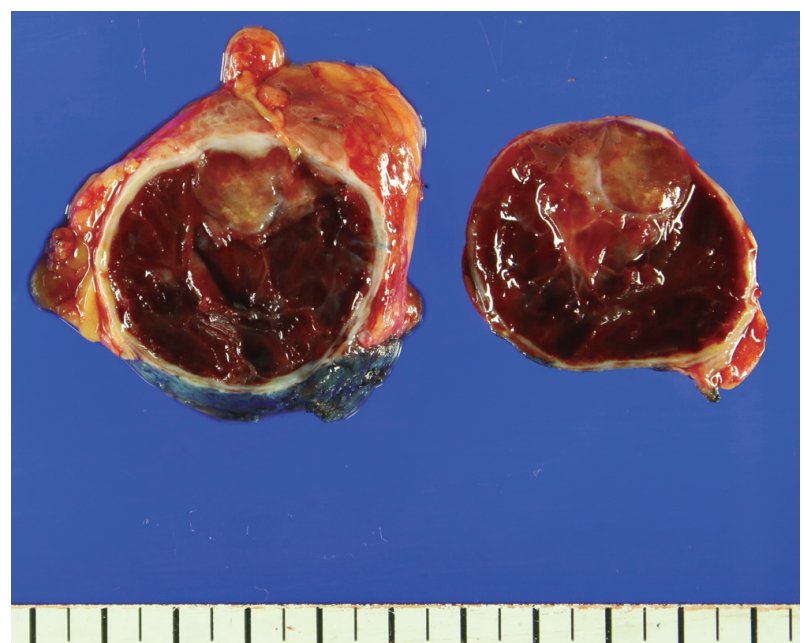

Fig. 1. Cut surface of the tumor showing yellowish solid mass with surrounding hemorrhagic area.

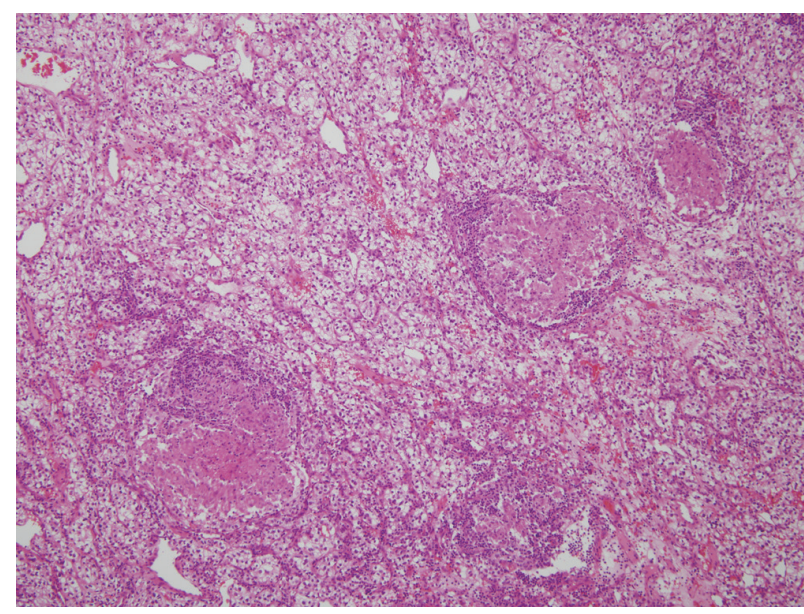

Fig. 2. Several epithelioid granulomas in the clear cell renal cell carcinoma.

multinucleated giant cells were scattered within the tumor stroma (Fig. 2). A few granulomas contained foci of coagulative necrosis, but they were devoid of caseation necrosis that is characteristic of tuberculosis (Fig. 3). Distribution of the granulomas showed no zonation pattern. Mild lymphocytic infiltration accompanied those granulomas.

As the performed procedure was a partial nephrectomy, evaluation of uninvolved renal parenchyma was limited. The parenchyma immediately surrounding the tumor showed no granulomatous reaction.

On Ziehl-Neelsen and Grocott's methenamine silver stains, no acid-fast bacteria or other microorganisms were identified. Polymerase chain reaction for Mycobacterium species yielded negative result.

On a follow-up CT scan taken 5 months after the operation,

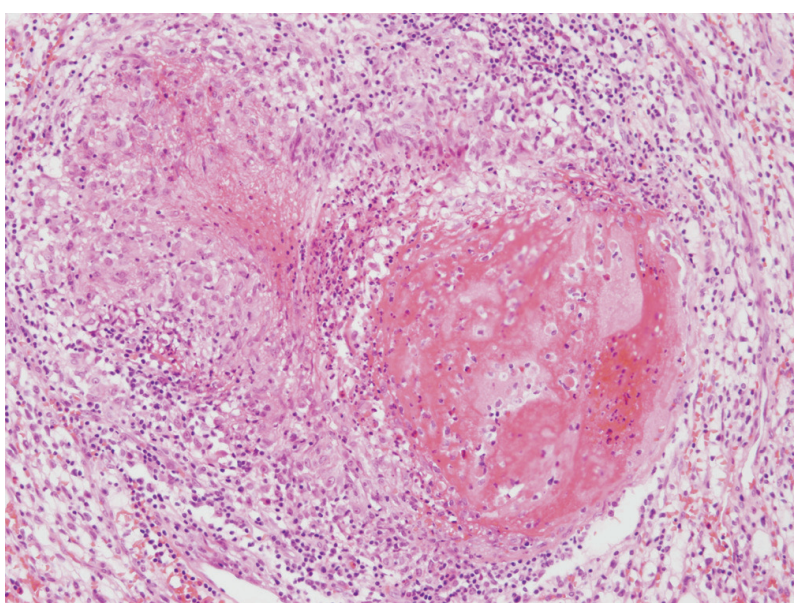

Fig. 3. A granuloma showing a focus of coagulative necrosis.

any evidence of recurrence was not detected.

\section{DISCUSSION}

Tumor-related SLR is postulated to occur due to T cell-mediated reaction against various cancer-associated antigens. ${ }^{7}$ Those antigenic factors are believed to be expressed directly by the cancer cells or shed as soluble antigen during tumor destruction. As those antigenic factors are conveyed by nearby lymphatic system, tumor-related SLR is most commonly identified in tumor-draining lymph nodes. ${ }^{8}$ Kurata et al. ${ }^{9}$ studied distribution of various kinds of inflammatory cells in lymph nodes with tumorrelated SLR. In this study, tumor-related SLR mainly appeared in lymphoid sinuses and T-cell zones in a continuous growth pattern. This finding supports the hypothesis that tumor-related SLR occurs because of tumor-shed antigens drained into lymph nodes. Granulomas in lymph nodes may be observed without any evidence of metastasis.

The association of renal cell carcinoma and granulomatous reaction is a rare phenomenon. Only fewer than 15 cases have been reported in the English literature since early 1990s. 3,7,8,10-13 We reviewed the clinical and pathological characteristics of previously reported cases. Those clinicopathologic details are summarized in Table 1. Of the 13 cases reviewed, there was a male preponderance ( 9 males and 4 females). In reports which included the side of affected kidney, seven out of 10 cases occurred in the right kidney. Tumor size ranged from 2.3 to $9.5 \mathrm{~cm}$. Most cases manifested as clear cell type, except for one case of sarcomatoid renal cell carcinoma. ${ }^{3}$ Fuhrman nuclear grade ranged from 1 to 4 , but there was only one case with grade 4 histology which was the sarcomatoid renal cell carcinoma case. Of 12 CCRCCs with 
Table 1. Reported cases of granulomatous reaction associated with CCRCC

\begin{tabular}{|c|c|c|c|c|c|c|c|c|c|}
\hline Source & Year & Age/Sex & Side & $\begin{array}{l}\text { No. of } \\
\text { cases }\end{array}$ & $\begin{array}{l}\text { Locations of } \\
\text { granulomas }\end{array}$ & $\begin{array}{l}\text { Histologic } \\
\text { type }\end{array}$ & $\begin{array}{l}\text { Fuhrman } \\
\text { grade }\end{array}$ & $\begin{array}{l}\text { Tumor size } \\
\text { (cm) }\end{array}$ & Follow-up period \\
\hline Hes et al. ${ }^{7}$ & 2003 & $\begin{array}{l}\text { 73-85 } \\
\text { (mean 78.3)/ } \\
\text { 2F, } 1 \mathrm{M}\end{array}$ & Unstated & 3 & Within tumor & Clear cell & 1 & $\begin{array}{l}2.3-7.0 \\
(\text { mean 4.4) }\end{array}$ & $6 \mathrm{mo}-4 \mathrm{yr}$ \\
\hline Kovacs et al. ${ }^{16}$ & 2004 & $62 / \mathrm{F}$ & Left & 1 & $\begin{array}{l}\text { Within tumor and } \\
\text { fibrous stroma } \\
\text { surrounding the } \\
\text { tumor }\end{array}$ & Clear cell & $\begin{array}{l}\text { Not } \\
\text { documented }\end{array}$ & 6 & $15 \mathrm{mo}$ \\
\hline Piscioli et al. ${ }^{3}$ & 2008 & 70/M & Right & 1 & $\begin{array}{l}\text { Periphery of the } \\
\text { tumor }\end{array}$ & Sarcomatoid & 4 & 7 & $\begin{array}{l}\text { Died of metastases } \\
\text { after } 6 \mathrm{mo}\end{array}$ \\
\hline Shah et al. ${ }^{13}$ & 2010 & $62 / \mathrm{M}$ & Left & 1 & Within tumor & Clear cell & 1 & 5 & $12 \mathrm{mo}$ \\
\hline $\begin{array}{l}\text { Narasimhaiah } \\
\text { et al. }{ }^{12}\end{array}$ & 2011 & $44-65 / 3 \mathrm{M}$ & Right & 3 & $\begin{array}{l}\text { Within tumor and } \\
\text { fibrous stroma } \\
\text { surrounding the } \\
\text { tumor }\end{array}$ & Clear cell & $1-3$ & $3-7$ & Not documented \\
\hline Ouellet et al. ${ }^{8}$ & 2012 & $62 / \mathrm{M}$ & Right & 1 & $\begin{array}{l}\text { Peritumoral only, } \\
\text { without } \\
\text { intratumoral } \\
\text { granulomas }\end{array}$ & Clear cell & 3 & 3.5 & $30 \mathrm{mo}$ \\
\hline Burhan et al. ${ }^{11}$ & 2013 & $62 / \mathrm{M}$ & Right & 1 & Within tumor & Clear cell & 3 & 9 & Not documented \\
\hline Khatua et al. ${ }^{10}$ & 2015 & $42 / F$ & Left & 1 & Within tumor & Clear cell & 2 & 9.5 & $1 \mathrm{yr}$ \\
\hline Present case & 2016 & $56 / \mathrm{M}$ & Right & 1 & Within tumor & Clear cell & 2 & 5.3 & $5 \mathrm{mo}$ \\
\hline
\end{tabular}

CCRCC, clear cell renal cell carcinoma; $F$, female; $M$, male.

tumor-related SLRs, three cases had documented the absence of sarcomatoid component. ${ }^{8,10}$ There was no mention of sarcomatoid differentiation in the rest of the cases.

All of the cases exhibited epithelioid granulomatous reaction related to the tumor. In the majority including this study (8 out of 13), granulomas existed only in tumor stroma. Four cases had granulomas both in the tumor stroma and fibrous stroma immediately surrounding the tumor. Piscioli et $a l^{3}$ reported a case of sarcomatoid renal cell carcinoma (RCC) containing granulomas only in the periphery of the neoplasm.

The follow-up period varied form 4 months to 4 years. The patient with sarcomatoid RCC in the report of Piscioli et al. ${ }^{3}$ died from multiple disseminated metastatic disease 6 months after the diagnosis. Rest of the cases maintained disease-free status until the last follow-up.

Tumor-related SLR was reported to be associated with better prognosis or lower possibility of metastasis in Hodgkin's lymphoma, gastric adenocarcinoma ${ }^{2}$ and breast cancer. ${ }^{4}$ In contrast, Tomimaru et al. ${ }^{14}$ found that sarcoid reaction identified in regional lymph nodes did not lead to better prognosis in lung cancer. As granulomatous reaction is thought to give protective function against infectious agents, tumor-related SLR might also aid in destruction of tumor cells. Activation of immune system is known to cause regression of tumors in various malignancies. ${ }^{15}$ Likewise, tumor-related SLR may be a immunologic defense mechanism against tumor cells, decreasing the metastasis rate and expansion of the tumor. However, tumor-related SLR may only be secondary phenomenon due to tumor-shed antigens. In Table 1, there is a case without recurrence or distant metastasis after a long follow-up period ( 4 years), ${ }^{7}$ but this does not support the hypothesis that tumor-related SLR is associated with better prognosis. In the reviewed cases, only one patient died of distant metastases during the follow-up period (6 months). ${ }^{3}$ However, that patient was diagnosed with a sarcomatoid RCC, which is known to show aggressive clinical course. Thus, the relationship between sarcoid reaction and tumor prognosis is yet to be defined.

In summary, we describe a rare case of CCRCC with intratumoral granulomatous reaction in a male patient, without evidence of systemic sarcoidosis or tuberculosis. We reviewed clinicopathologic findings of previously reported cases with similar histologic features. Further research is required to clarify the mechanism of tumor-related SLR and its impact on prognosis.

\section{Conflicts of Interest}

No potential conflict of interest relevant to this article was reported.

\section{REFERENCES}

1. Kumar V, Abbas AK, Aster JC. Robbins and Cotran pathologic basis of disease. 9th ed. Philadelphia: Elsevier/Saunders, 2015. 
2. Brincker H. Sarcoid reactions in malignant tumours. Cancer Treat Rev 1986; 13: 147-56.

3. Piscioli I, Donato S, Morelli L, Del Nonno F, Licci S. Renal cell carcinoma with sarcomatoid features and peritumoral sarcoid-like granulomatous reaction: report of a case and review of the literature. Int J Surg Pathol 2008; 16: 345-8.

4. Pavic M, Debourdeau P, Vacelet V, Rousset H. Sarcoidosis and sarcoid reactions in cancer. Rev Med Interne 2008; 29: 39-45.

5. Bassler R, Birke F. Histopathology of tumour associated sarcoidlike stromal reaction in breast cancer: an analysis of 5 cases with immunohistochemical investigations. Virchows Arch A Pathol Anat Histopathol 1988; 412: 231-9.

6. Okumura N, Teramachi M, Okada K, Itoh M, Inoue R, Kobayashi K. A case report of lung cancer with sarcoid-like reaction in the primary tumor and regional lymph nodes. Nihon Kyobu Shikkan Gakkai Zasshi 1987; 25: 360-4.

7. Hes $\mathrm{O}$, Hora $\mathrm{M}$, Vanecek $\mathrm{T}$, et al. Conventional renal cell carcinoma with granulomatous reaction: a report of three cases. Virchows Arch 2003; 443: 220-1.

8. Ouellet S, Albadine R, Sabbagh R. Renal cell carcinoma associated with peritumoral sarcoid-like reaction without intratumoral granuloma. Diagn Pathol 2012; 7: 28.

9. Kurata A, Terado Y, Schulz A, Fujioka Y, Franke FE. Inflammatory cells in the formation of tumor-related sarcoid reactions. Hum Pathol 2005; 36: 546-54.

10. Khatua S, Bose K, Bandyopadhyay A, Banerjee A. A rare association of sarcoid-like granuloma with renal cell carcinoma. J Cancer Res Ther 2015; 11: 1033.

11. Burhan W, Al Rowaie Z, Rajih E, Akhtar M. Sarcoid-like granulomatous reaction in renal cell carcinoma: report of a case with review of the published reports. Ann Saudi Med 2013; 33: 614-8.

12. Narasimhaiah DA, Manipadam MT, Aswathaman K, Krishnamoorthy S. Renal cell carcinoma associated with granulomatous reaction. Saudi J Kidney Dis Transpl 2011; 22: 1211-4.

13. Shah VB, Sharma P, Pathak HR. Conventional clear renal cell carcinoma with granulomatous reaction. Indian J Pathol Microbiol 2010; 53: $379-80$.

14. Tomimaru Y, Higashiyama M, Okami J, et al. Surgical results of lung cancer with sarcoid reaction in regional lymph nodes. Jpn J Clin Oncol 2007; 37: 90-5.

15. Ricci SB, Cerchiari U. Spontaneous regression of malignant tumors: importance of the immune system and other factors (review). Oncol Lett 2010; 1: 941-5.

16. Kovacs J, Varga A, Bessenyei M, Gomba S. Renal cell cancer associated with sarcoid-like reaction. Pathol Oncol Res 2004; 10: 169-71. 